lack of professionals and specialised centers. In the future we should strive for opening free counselling (paediatricians, educational rehabilitator, speech therapist and psychologists) for parents with doubts at primary health centers.

\section{CAN BENIGN AFEBRILE CONVULSIONS ASSOCIATED WITH MILD GASTROENTERITIS BE PREVENTED BY VACCINATION?}

S Bela Klancir*, I Mrkić Kobal, G Krakar, F Sabol, M Kovač Šižgorić, G Tešović, M Meštrović, S Delin, R Gjergja Juraški, V Đuranović, Z Sabol. Sabol Outpatient Clinic for Sick Children, Zagreb, Croatia

\subsection{6/archdischild-2021-europaediatrics.488}

Convulsions during mild viral gastroenteritis (CwG) represent an entity of benign afebrile seizures occurring in children worldwide. Recent reports have shown that after the introduction of RV vaccine the incidence of $\mathrm{RV}$-associated $\mathrm{CwG}$ decreased.

Our aim was to evaluate the demographic, electroclinical characteristics and outcome of $\mathrm{CwG}$ in children hospitalized in 6 Croatian centers in the period from 2008 to 2018.

This is a multicentre prospective study that included 40 patients hospitalized for CwG (male to female ratio 25:15). We collected medical records including data on gender, personal, family history of epileptic seizures, age on the time of first seizure, clinical type, duration and frequency of seizures, postictal/interictal electroencephalographic (EEG) features, antiepileptic therapy and the results of laboratory analysis (including stool specimens for virus antigens and bacterial stool specimen culture) and brain imaging. Patients follow up was performed in six-months intervals during the first two years and later at intervals of 12-18 months.

Seizure types were classified using most current revised ILAE terminology.

The median age of children at the time of CwG onset was 15.5 months (range: 1 month to 6 years). Rotavirus was the most common cause of diarrhoea $(85 \%)$. Seizures most frequently occurred (45\%) on the third day of the gastrointestinal symptoms. Generalized seizures (90\%) were the most common clinical presentation. In a half of patients, the seizures came in clusters.

The attacks usually lasted for less than five minutes (85\%). In about half of the patients seizures ceased spontaneously and usually lasted less than five minutes (85\%). Abnormal EEG was reported in 6 of 40 patients with CwG (15\%). Long-term antiepileptic therapy (phenobarbitone and valproic acid) was prescribed in $12 / 40$ patients (30\%) for 1-24 months. During the follow-up period (median duration 44.5 months) of 37 children with CwG, two children (5.4\%) had recurrence of $\mathrm{CwG}$, two patients had febrile seizures and two children developed epilepsy.

Afebrile CwG represent a quite clearly defined clinical condition with good prognosis and with normal psychomotor development in most children. In a small number of cases, the risk of recurrence of $\mathrm{CwG}$ may exist, with the risk of the onset of febrile seizures and the development of epilepsy.

Considering RV as the most common causative agent of diarrhoea associated with convulsions, universal vaccination with RV vaccines should reduce the incidence of morbidity from RV disease and consequently reduce the occurrence of its complications - CwG.

\section{PEDIATRIC PRIMARY HEALTH CARE IN EARTHQUAKE- AFFECTED AREAS OF SISAK-MOSLAVINA COUNTY DURING THE COVID-19 PANDEMIC}

${ }^{1}$ Mirjana Kolarek Karakaš*, ${ }^{1}$ Branka Pirija, ${ }^{1}$ Martina Rastovac, ${ }^{2}$ Milan Stanojević, ${ }^{2}$ Anita Pavičić Bošnjak, ${ }^{1,2}$ Josip Grgurić. ${ }^{1}$ Croatian Society for Preventive and Social Pediatrics of Croatian Medical Association; ${ }^{2}$ UNICEF Office Croatia

\subsection{6/archdischild-2021-europaediatrics.489}

Aim To present the organization of pediatric primary health care in Sisak-Moslavina County in the complex conditions of lack of staff, facilities, and equipment after the earthquake during the COVID-19 pandemic.

Background The COVID-19 pandemic spread to Croatia on February 25, 2020, which required a change in the organization of health care institutions and the provision of health services with as few contacts as possible between staff and patients. Besides, Sisak-Moslavina County on December 29, 2020 hit by a strong earthquake that destroyed most of the facilities of the health care system. The pandemic and earthquake have affected adversely the physical, mental, and social well-being of children and their families.

Results In 2020749 newborns were born In the Sisak maternity hospital, and about 13,000 children live in the earthquake-affected area. Primary pediatric care covers 8,348 children up to 14 years of age, of which 4,736 children up to 7 years of age are cared for by 7 primary pediatric teams. Out of 4 pediatric outpatient clinics (covered by 3 pediatric teams) in Sisak caring for 5,140 children, two work in containers, and one is dislocated in the suburbs of Sisak. From Glina, the primary pediatric outpatient office caring for 1,247 children was moved to Topusko. In the Petrinja area, two primary pediatric teams are working at the same location as before the earthquake and caring for a total of 1,961 children. Thanks to the UNICEF Office for Croatia and the Ministry of Health of the Republic of Croatia, containers, and the most necessary equipment for pediatric teams were acquired. The salutogenic approach to the health of families and children was maintained in an emergency, which included breastfeeding support, continued implementation of pediatric preventive health care measures, including vaccination, care for vulnerable groups of children with disabilities and socially deprived children, and intersectoral cooperation.

Conclusions It is needed to increase awareness of the community that delivering pediatric health care in emergencies is essential and could be realized if the appropriate number of health care teams is available. Ensuring spatial and all other conditions for their work should be the highest priority in restoration after the earthquake.

\section{\begin{tabular}{l|l}
\hline 490 & THE SHORT-TERM EFFECTS OF STRUCTURED
\end{tabular} EDUCATION ON BREAST-FEEDING IN A SAMPLE OF STUDENTS FROM BJELOVAR}

Marija Čatipović*, Željka Ostović, Marina Rajn, Josip Grgurić. Specijalistička pedijatrijska ordinacija Marija Čatipović

10.1136/archdischild-2021-europaediatrics.490 
The Goal The aim of this study was to examine the effectiveness of structured education about breast-feeding using a sample of high-school students. The results presented in this study are part of the results of wider research, currently on-going, into the influence of structured education on breast-feeding on changes to the intentions, knowledge and attitudes of pupils and students.

Methods The study was longitudinal, quasi-experimental, and approved by the Ministry of Science and Education of the Republic of Croatia. The experimental group consisted of 30 students from the Medical High School in Bjelovar, and the control group consisted of 30 other students from the same school. The experimental group took a structured educational course on breast-feeding, and the control group did not. The attitudes, intentions and knowledge of the subjects were measured using a validated BIAKQ questionnaire. In both groups the questionnaire was conducted twice, with a twoweek interval. The outcomes measured were the changes to the total results of the BIAKQ questionnaire and the subscales of the questionnaire. In processing the results, the following statistical procedures were used: presentation of the results by frequencies, percentages, arithmetic means and standard deviations, analysis of outliers and the normality of distribution of the results (Skewness and Kurtosis $\mathrm{z}$ values, Histogram, Q-Q diagram, Box diagram, Kolmogorov-Smirnov and Shapiro-Wilk tests), analysis of the differences between the results (t-test or the Mann-Whitney test and Wilcoxon test), and correlations are presented using Spearman's correlation coefficient.

Results Before the educational course, in relation to intentions, attitudes, knowledge and the overall results of the questionnaire, there were no significant differences between the control and experimental groups. After the experimental group had taken the educational course, the subjects achieved better results in comparison to the control group in terms of their intentions $(\mathrm{ME}=38.03, \mathrm{SD}=5.71$, $\mathrm{MK}=35.27, \quad \mathrm{SD}=5.41, \quad \mathrm{t}(58)=1.76, \quad \mathrm{p}=0.08), \quad$ attitudes $(\mathrm{MdnE}=35.52, \mathrm{MdnK}=25.48, \mathrm{U}=299.5, \mathrm{p}=0.03)$. knowledge $(\mathrm{MdnE}=35.97, \mathrm{MdnK}=25.03, \mathrm{U}=286.0, \mathrm{p}=0.01)$ and the total results of the questionnaire $(\mathrm{MdnE}=35.23$, $\mathrm{MdnK}=25.77, \mathrm{U}=308.0, \mathrm{p}=0.04)$. The results of the subjects in the experimental group after the course were also better in relation to their own results before the course, in terms of their intentions $(M=4.40, S D=5.61, t(29)=4.30$, $\mathrm{p}=0.00), \quad$ attitudes $\quad(M=13.40, \quad S D=15.37, \quad \mathrm{t}(29)=4.77$, $\mathrm{p}=0.00)$, knowledge $(\mathrm{MdnPos}=8.85, \quad \mathrm{MdnNeg}=9.5, \quad \mathrm{Z}=-$ $1.883, \mathrm{p}=0.06)$ and total results $(\mathrm{MdnPos}=15.69$, $\mathrm{MdnNeg}=9.0, \mathrm{Z}=-4.121, \mathrm{p}=0.00)$. The greatest correlation in the total results of the questionnaire after the course were shown by attitudes $(r=0.99, p=0.00)$, and the smallest by knowledge, before $(r=0.39, p=0.04)$ and after $(r=0.29$, $\mathrm{p}=0.12$ ) the educational course.

Conclusion The results confirm statistically significantly improved attitudes, intentions and knowledge regarding breastfeeding in the experimental group after taking the educational course. Earlier research by the author and research by other authors confirm that education that only brings about changes in knowledge does not necessarily also lead to changes in attitudes and intentions. Only a well-designed and structured model of education, with a multi-dimensional approach can lead to changes in attitudes and intentions, which are important predictors of behaviour. Further research is needed to define more precisely the age at which education gives the best results.

\section{A CASE REPORT OF NEUROFIBROMATOSIS TYPE 1 IN TWO BROTHERS. PRIMARY PEDIATRIC HEALTH CARE OF A CHILD WITH A CHRONIC CONDITION IN CROATIA}

Branka Pirija*. Pediatric primary care Branka Pirija MD, paediatrician

10.1136/archdischild-2021-europaediatrics.491

Introduction Neurofibromatosis Type 1 (NF1) or von Recklinghausen disease is an autosomal dominant genetic disease characterized by variability of its clinical expression of sick members of the same family. In a National Institutes of Health (NIH) consensus development conference regarding NF1, seven criteria were demarcated, of which two or more are required to establish the diagnosis of NF1. Some features of NF1 can be present at birth, but most manifestations emerge with age. Various manifestations and complications are associated with the age of the patient.

Case Description In this case, a mother and two male children have NF1. The diagnosis of NF1 in the first child was suspected based on cafe au lait macules at 6months of age. At the same time, a clinical diagnosis was made in a 28 -year-old mother. Child1, a male, 7years old, has multiple café au lait macules, axillary and inguinal freckling, subcutaneous neurofibromas, Lisch nodules, multiple T2-hyperintensities on brain magnetic resonance imaging (MRI) in the basal ganglia, cerebellum. He has macrocephaly, cognitive problems, attention deficit, sideropenic anaemia. MLPA analysis (Multiplex Ligation-dependent Probe Amplification test with SALSA MLPA kit P245-B1) showed no change in the number of copies of the genome. Child2, a male, aged 4years and 3months, with the presence of multiple café au lait spots diffuse all over the body of different sizes and axillary freckles. Brain MRI shows hyperintensities in the basal ganglia, globus pallidus and cerebellum. He has constipation, no sphincter control, sideropenic anaemia, fine motor skills difficulties. Both children have speech articulation difficulties. Child1 attends school according to an individual program. Child2 does not attend kindergarten, is not included in the early intervention program. 34year-old mother, a housewife, has an unrecognized NF1. During puberty, she had skin problems, spots and neurofibromas, itching. The family live in a house in the countryside, no car, no internet access. Public transport to the school, kindergarten and the nearest town is not organized. There are no speech therapists near the place of residence.

Conclusion Health surveillance of children with NF1 in primary pediatric care requires knowledge of clinical criteria and the various manifestations of the disease that may occur with age. NF1 is a multisystem disorder that requires multidisciplinary follow-up. Primary paediatrician takes on the role of coordinator. It is necessary to know the ability of the family to meet the intense rhythm of diagnostic and therapeutic interventions.

\section{CAN BENIGN AFEBRILE CONVULSIONS ASSOCIATED WITH MILD GASTROENTERITIS BE PREVENTED BY VACCINATION?}

Svjetlana Bela Klancir*, I Mrkić Kobal, G Krakar, F Sabol, Kovač Šižgorić, G Tešović, M Meštrović, S Delin, R Gjergja Juraški, V Đuranović, Z Sabol. Poliklinika za dječje bolesti dr. Sabol

10.1136/archdischild-2021-europaediatrics.492

Background Convulsions during mild viral gastroenteritis (CwG) represent a clinically recognized entity of benign 